\title{
Career pathways and ladders for photonics technicians
}

\section{Arthur Guenther, Daniel Hull}

Arthur H. Guenther, Daniel M. Hull, "Career pathways and ladders for photonics technicians," Proc. SPIE 9664, Ninth International Topical Meeting on Education and Training in Optics and Photonics, 96641V (24 October 2005); doi: 10.1117/12.2207678

SPIE Event: Ninth International Topical Meeting on Education and Training in Optics and Photonics, 2005, Marseille, France 


\title{
Ref ETOP024
}

\section{Career Pathways and Ladders for Photonics Technicians}

\author{
Arthur H. Guenther ${ }^{1}$ \& Daniel M. Hull ${ }^{2}$
}

${ }^{1}$ Center for High Technology Materials, University of New Mexico, Albuquerque, New Mexico ${ }^{2}$ CORD Waco, Texas

Introduction

\section{Summary}

Since operational lasers were first demonstrated in 1960, the field of laser/electro-optics has become an indispensable, rapidly expanding component of modern industry. With the emergence of numerous medical and telecommunication applications in the 1980s, including fiber-optics, the field of laser/electro-optics evolved into photonics, a broad field encompassing optoelectronics, micro-optics, lasers, digital imaging, spectroscopy, optical instruments, and optical systems. Today photonics is not only a technology field in and of itself but is also an enabler of nearly every other technology field, including microtechnology, measurement and materials processing, remote sensing, photolithography for semiconductors, nanotechnology, electro-optics displays and imaging, and national defense.

Rapid growth in the number and complexity of photonics and photonics-enabled technologies has significantly increased the demand for technicians in photonics and related fields. According to a recent survey of employers, the number of U.S. technical jobs in photonics and photonicsenabled technologies is expected to grow an average of more than 1800 per year through 2009, a trend that represents an increase of more than 6 percent per year (Figure 1). ${ }^{2}$ This trend is consistent with the findings of a study by the National Research Council, the administrative arm of the U.S. National Academies of Science and Engineering, which concluded that optics and photonics will be the principal technology-based economic driver of the 21 st Century. ${ }^{3}$

\footnotetext{
${ }^{2}$ Darrell Hull and Agustin Navarra, "Photonics Technician Employment Projections: An Industry Survey Report" (unpublished manuscript). Projections based on survey responses from an available population of businesses taken from the Laurin Publishing Company's Corporate Directory.

${ }^{3}$ Harnessing Light: Optical Science and Engineering for the 21 st Century (National Academy Press, 1998).
} 


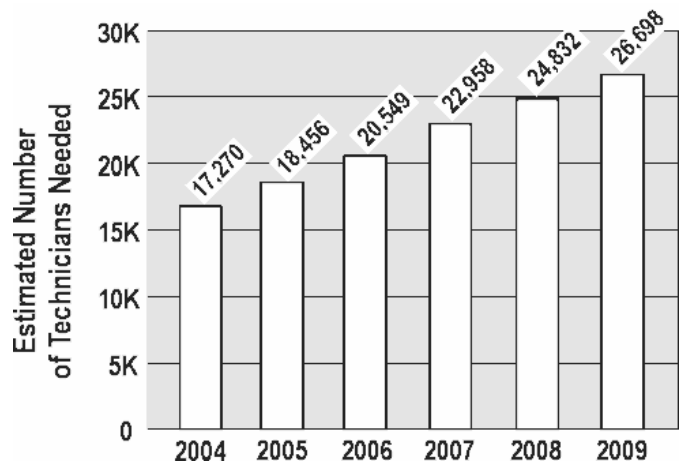

Figure 1. U.S. Photonics Technician Employment Trend

Most of the current and projected positions for technicians in optics, photonics, and photonics-enabled technologies require postsecondary education and training, but not necessarily baccalaureate degrees. The preferred credential is the associate degree. Consequently, the rapid growth of optics and photonics applications, along with the projected need for new photonics technicians, is placing a growing - and largely unmet-demand on twoyear postsecondary educational institutions. Not only in the United States but in other countries as well, the capacity of existing two-year postsecondary programs in photonics and related fields is insufficient to meet the anticipated demand for technicians. The availability of up-to-date curricula in those fields is also severely limited.

The effects of the shortage of programs and curricula at the postsecondary level are compounded by conditions at the secondary level. The weak math and science skills of many high school students disqualify them from entering demanding technical postsecondary programs. Moreover, very few high schools effectively alert students to the numerous career opportunities available in optics and photonics. In the main, the majority of secondary schools fall short in attracting young people to, and preparing them for, this exciting, rewarding, and expanding field.

This situation calls for a six-to-eight-year, secondary-postsecondary photonics education pipeline, that is, an educational pathway leading from the early years of high school through the associate degree and beyond. The envisioned pipeline would provide a means for high school students to begin to focus on optics and photonics early (preferably beginning in the ninth grade), lay a solid foundation in math and core science skills, acquire strong employability skills (e.g., communication, problem solving, and teamwork), earn college credits through dual enrollment and articulation, and gain work-based experiences (including paid internships). Following high school graduation, students in the pipeline would be well prepared to enter demanding two-year technical programs and, in many cases, would already have postsecondary credits in hand.

The need for a photonics pipeline in the United States is being met through the partnering of secondary and postsecondary schools and businesses in what are called Career Pathways. ${ }^{4}$

\footnotetext{
${ }^{4}$ The most up-to-date and comprehensive book on Career Pathways is coauthor Dan Hull's just-released Career Pathways: Education with a Purpose (Waco, Texas: CORD, 2005).
} 
This innovative movement is an outgrowth of the Tech Prep/Associate Degree programs that have evolved in the United States since 1990. ${ }^{5}$ Representatives from secondary and postsecondary institutions have met with employers in broad-based partnerships designed to prepare students for groups of occupations (i.e., "career clusters") by creating unified curricula that align high school course offerings with college offerings, thereby ensuring that students are well-qualified to make the transition from secondary to postsecondary without course duplication or remediation.

A Career Pathway is a carefully coordinated sequence of rigorous academic and technical courses that begins in the ninth grade and leads to an associate degree, industry-recognized certificate, licensure, and/or baccalaureate degree or higher. Each Career Pathway is developed, implemented, and maintained by a partnership involving secondary and postsecondary education, business, and employers. In most cases, Career Pathway students have opportunities to earn college credits in their chosen technical fields while still in high school. In addition to classroom work and laboratories, Career Pathways normally involve paid student internships for which the students receive credit toward their secondary and postsecondary diplomas.

The vertical coordination of Career Pathways helps to identify and remedy potential problems before they can adversely affect students' progress. For example, secondary students in the Photonics Pathway are assessed for their mathematics ability early in high school. Where weaknesses are identified, the students are given specialized support as needed to prepare them to move from each rung on the educational ladder to the next.

\section{The Albuquerque Model}

An exemplary model of an Optics and Photonics Career Pathway is a partnership in Albuquerque, New Mexico, involving the Photonics Academy at West Mesa High School (WMHS), TVI Community College, and the University of New Mexico. Students are recruited into the program via outreach activities targeting WMHS's three feeder middle schools. Those activities include laser demonstrations (always popular with students), presentations by employers and other professionals, printed materials, videos, and many "gee whiz" experiences provided by professional societies and other partners.

Each Photonics Academy student follows an articulated 4+2 course sequence similar to the one pictured in Figure $2 .{ }^{6}$ The curriculum is designed to impart the skills identified by area employers as essential to success in New Mexico's high-tech environment, in which photonicsand optics-enabled technologies are especially prominent.

\footnotetext{
${ }^{5}$ See Dan Hull and Dale Parnell, Tech Prep Associate Degree: A Win/Win Experience (Waco, Texas: CORD, 1991).

${ }^{6}$ Source: The National Photonics Skill Standards for Technicians (Waco, Texas: CORD, 2003), p. 53. The same document provides skill standards for six photonics-enabled technologies (communication, lighting and

illumination, medicine, manufacturing, imaging and remote sensing, and optoelectronics), foundational knowledge components for two-year photonics education programs, and outlines for three high school courses and eight postsecondary courses pertaining to the optics and photonics pathway.
} 


\begin{tabular}{|c|c|c|c|c|c|c|c|}
\hline & Grade & English & Mathematics & Science & Technology & Technology & Other \\
\hline \multirow{2}{*}{$\begin{array}{l}\text { 들 } \\
\text { 웧 } \\
\text { 훈 }\end{array}$} & 9 & English I & Algebra I & $\begin{array}{c}\text { Biology / } \\
\text { Life Sciences }\end{array}$ & $\begin{array}{l}\text { Career } \\
\text { Management } \\
\text { Success }\end{array}$ & & \multirow{4}{*}{ 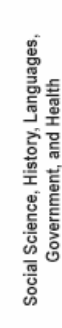 } \\
\hline & 10 & English II & Geometry & Chemistry & $\begin{array}{l}\text { Computer } \\
\text { Applications }\end{array}$ & & \\
\hline \multirow{2}{*}{ 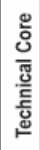 } & 11 & English III & Algebra II & Physics & $\begin{array}{c}\mathrm{DC} / \mathrm{AC} \\
\text { Electronics }\end{array}$ & $\begin{array}{l}\text { Introduction } \\
\text { to Photonics }\end{array}$ & \\
\hline & 12 & English IV & Precalculus & $\begin{array}{l}\text { Materials } \\
\text { Science }\end{array}$ & $\begin{array}{c}\text { Digital } \\
\text { Electronics* }\end{array}$ & $\begin{array}{l}\text { Technical } \\
\text { Elective** }\end{array}$ & \\
\hline \multirow{4}{*}{ 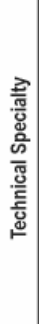 } & $\begin{array}{c}13 \\
\text { 1st Semester }\end{array}$ & English & $\begin{array}{l}\text { Electronic } \\
\text { Circuits for } \\
\text { Photonics }\end{array}$ & $\begin{array}{l}\text { College } \\
\text { Physics }\end{array}$ & $\begin{array}{l}\text { Fundamentals } \\
\text { of Light } \\
\text { and Lasers }\end{array}$ & $\begin{array}{l}\text { Optics and } \\
\text { Optical } \\
\text { Components }\end{array}$ & \multirow{4}{*}{ 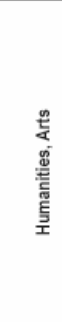 } \\
\hline & $\begin{array}{c}13 \\
\text { 2nd Semester }\end{array}$ & $\begin{array}{c}\text { Technical } \\
\text { Communication }\end{array}$ & $\begin{array}{l}\text { Calculus or } \\
\text { Other Advanced } \\
\text { Math }\end{array}$ & $\begin{array}{c}\text { Advanced } \\
\text { Digital Electronics }\end{array}$ & $\begin{array}{l}\text { Elements of } \\
\text { Photonics }\end{array}$ & $\begin{array}{c}\text { Optical } \\
\text { Detection and } \\
\text { Measurement }\end{array}$ & \\
\hline & $\begin{array}{c}14 \\
\text { 1st Semester }\end{array}$ & Humanities & $\begin{array}{l}\text { Photonics } \\
\text { Specialty }\end{array}$ & $\begin{array}{l}\text { Technical } \\
\text { Support }\end{array}$ & $\begin{array}{c}\text { Fiber Optics } \\
\text { and Telecommuni- } \\
\text { cation }\end{array}$ & $\begin{array}{l}\text { Lasers and } \\
\text { Other Light } \\
\text { Sources }\end{array}$ & \\
\hline & $\begin{array}{c}14 \\
\text { 2nd Semester }\end{array}$ & Humanities & $\begin{array}{l}\text { Photonics } \\
\text { Specialty }\end{array}$ & $\begin{array}{l}\text { Technical } \\
\text { Support }\end{array}$ & $\begin{array}{l}\text { Imaging and } \\
\text { Display }\end{array}$ & $\begin{array}{l}\text { Photonics } \\
\text { Applications }\end{array}$ & \\
\hline
\end{tabular}

The twelfth-grade course Digital Electronics could be offered for dual (S/PS) credit.

The technical elective could be either of the first two college photonics courses, Fundamentals of Light and Lasers or Optics and Optical Components.

\section{Figure 2. An Example of a Photonics Technology 4+2 Course Sequence ${ }^{7}$}

The Photonics Academy is now over four years old and enrolls over 125 students per year. Admission is selective: Each year only 32 ninth graders are enrolled. Student interest in the program is very high. Last year over 90 students entering WMHS requested either the Photonics Academy program or a parallel Advanced Technology Academy program. The Photonics Academy makes every effort to be inclusive with respect to women and minorities. At WMHS, of the entering Photonics Academy students, approximately two-thirds are minority students and over half are female. As a result there is plenty of competition. Now, after four years, the average GPA is above 3.5 and is increasing as the program matures.

One of the greatest benefits of the Photonics Academy program is that each year Sandia National Laboratory selects several graduates for immediate half-time employment. Those students simultaneously complete associate degrees at TVI at Sandia's expense. The enrollment of TVl's photonics program is currently 55 students, most of whom have advanced academic standing. That number is significant, given that, in all probability, many of those students would otherwise no longer be in school. Thanks to the pipeline created by the WMHSTVI program, not only do those students enjoy the satisfaction of advanced standing toward AAS degrees, they are confident that they can complete their degrees and they have a clear sense of the steps they will take after completing their education.

\footnotetext{
${ }^{7}$ The term " $4+2$ " signifies four years of secondary coursework plus two years of postsecondary coursework.
} 
The Photonics Academy program gives students many options. Internships are available at all levels; most provide further credit toward the meeting of educational requirements. The program facilitates various combinations of simultaneous parttime school and work and enables students to exit and reenter as they gain experience, maturity, confidence, and knowledge on the job. The program also prepares them to continue their education beyond the associate degree level. Figure 3 provides a schematic of the program's levels and exit and reentry points.

Three additional activities and indicators are noteworthy. First, the program's directors have created a New Mexico Alliance for Optics and Photonics Education, whose many partners give of their time and financial support through equipment grants and other contributions. Second, WMHS has become the first high school chapter of a professional society (SPIE). And finally, through its constant efforts in curriculum development, CORD continues to create more advanced and up-to-date instructional modules through its NSF-funded STEP project (Scientific and Technological Education in Photonics, NSF DUE/ATE 0202424). CORD's pioneering efforts in the Career Pathways movement serve not only to promote optics and photonics education but education in other career fields as well.

Two important lessons learned through the Photonics Academy are that young learners are worth investing in, and that model programs like the Photonics Academy require committed teamwork. When Career Pathways partners leave their egos at the door and commit themselves to the greater good of the collective benefit of all participants, the results can be dramatic.

The three most important elements for the success of such a team effort are (1) a pipeline of students committed to careers in optics and photonics, (2) up-to-date, high-quality curricula in optics and photonics, and (3) continual involvement of employers in the support of these educational programs.

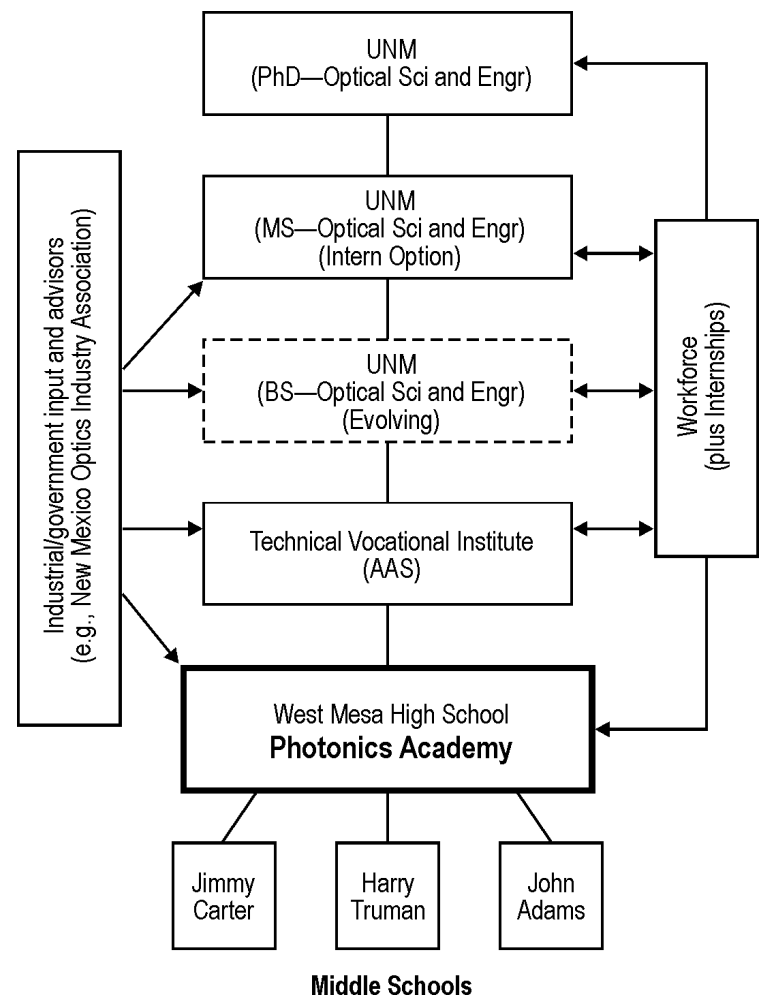

Figure 3. Education Ladder for Careers in Optics and Photonics: The Albuquerque Model 


\section{Acknowledgment}

The authors would like to express their appreciation to Mark Whitney and Leno Pedrotti of CORD for their input and suggestions, garnered from their experience relative to the subject of this paper.

Proc. of SPIE Vol. $966496641 \mathrm{~V}-6$

Downloaded From: https://www.spiedigitallibrary.org/conference-proceedings-of-spie on 26 Apr 2023 Terms of Use: https://www.spiedigitallibrary.org/terms-of-use 